\author{
Wiesław FRACZ ${ }^{1}$ \\ Grzegorz JANOWSKI ${ }^{2}$ \\ Grażyna RYZIŃSKA ${ }^{3}$
}

\title{
SELECTED ASPECTS OF MANUFACTURING AND STRENGTH EVALUATION OF POROUS COMPOSITES BASED ON NUMERICAL SIMULATIONS
}

\begin{abstract}
In this paper the numerical simulations of microcellular injection molding process for polymer composite with glass fiber for variable content of pores were carried out. In order to evaluate the strength of the three-phase composite structure (polypropylene PP as a matrix, $20 \%$ wt. of glass fiber GF and 1-9\% vol. of the pores) a microstructural analysis was performed and strength calculations were conducted using the Mori-Tanaka homogenization model. The analyzed product (the base of industrial mop) was subjected to the loading in Ansys 14.5 commercial code, considering the impact of pores content on its mechanical properties. Furthermore, the paper presents the visualization of calculated composite microstructure for variable pores contents.
\end{abstract}

Keywords: microcellular composites, numerical simulations, Digimat, Ansys, Mori-Tanaka homogenization method

\section{Introduction}

The injection foaming processes allow to manufacture products with a cellular structure. These methods consist of gas foaming dispensing to the plastic in the plastifying zone or directly in a cavity through a specially designed head, and injecting foam mixture into the mold [1]. The main type of injection foaming processes was designed and developed under the name Mucell®. In this process the volatile gasses such as carbon dioxide or nitrogen are added under a pressure to the plastics in supercritical state (Fig. 1) [2].

\footnotetext{
1 Autor do korespondencji/corresponding author: Wiesław Frącz, Rzeszow University of Technology, 8 Powstańców Warszawy Ave., 35-959 Rzeszów, e-mail: wf@prz.edu.pl

${ }^{2}$ Grzegorz Janowski, Rzeszow University of Technology, e-mail: gjan@ prz.edu.pl

${ }^{3}$ Grażyna Ryzińska, Rzeszow University of Technology, e-mail: grar@prz.edu.pl
} 


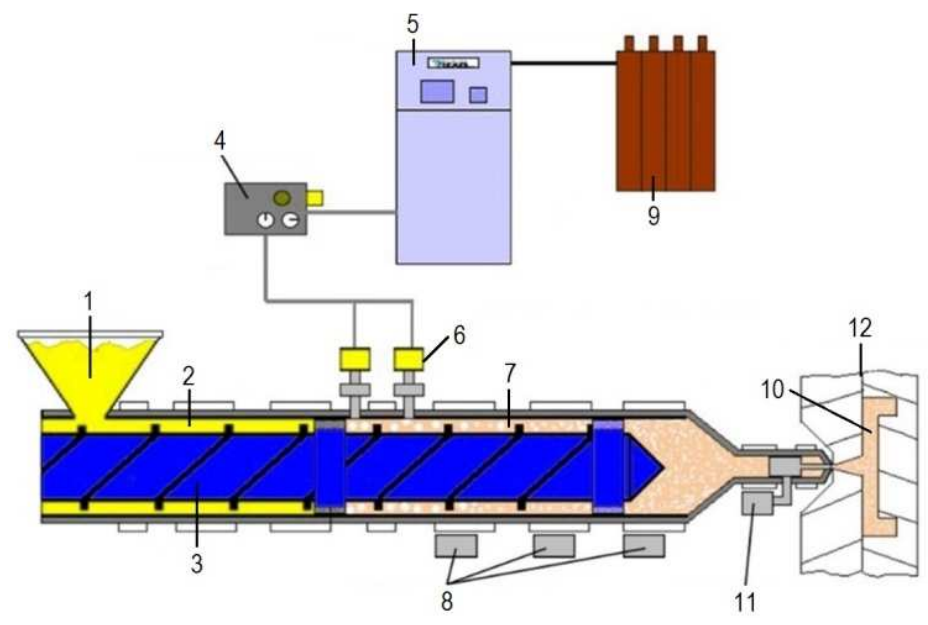

Fig. 1. Diagram of Mucell ${ }^{\circledR}$ microcellular injection molding process: 1 - hopper, 2 - plastic, 3 - screw, 4 - pressure regulator, 5 - dosage of critical gas, 6 - injection of supercritical gas, 7 - plastic with gas, 8 - cooling system of heaters, 9 - gas supply $\left(\mathrm{N}_{2}, \mathrm{CO}_{2}\right), 10$ - product, 11 - nozzle closed by a needle, 12 - injection mold.

The presence of blowing agents in a supercritical state makes it easier to dispense them to the plastics due to low compressibility (Fig. 2). Nitrogen reaches the supercritical state at the temperature of $-147^{\circ} \mathrm{C}$ and pressure of 3.4 $\mathrm{MPa}$ and carbon dioxide at the temperature of $31.1^{\circ} \mathrm{C}$, and pressure of 7.22 $\mathrm{MPa}$. The use of carbon dioxide results in viscosity reduction of the injected mixture allowing to manufacture products with complicated shapes. On the other hand, the foaming process with nitrogen extends the intensity reaction relative to carbon dioxide. In the Mucell ${ }^{\circledR}$ injection molding process it is not necessary to use the packing pressure thanks to the pressure of expanding gas in the pores. This fact results in generation of a large amount of micropores, as well as a reduction in the total injection time [3-5].

There may be distinguished four main stages of microcellular injection molding process (Fig. 3) [6]:

- diffusion of gases in plastic,

- production of germ pores - so-called ,nucleation process”, as a result of an abrupt change of thermodynamic material state,

- expansion of pores, where their size and number depend mainly on the pressure gradient and temperature, viscoelastic properties of polymer and the gas content,

- shaping of a product in the mold cavity by lowering of temperature. 


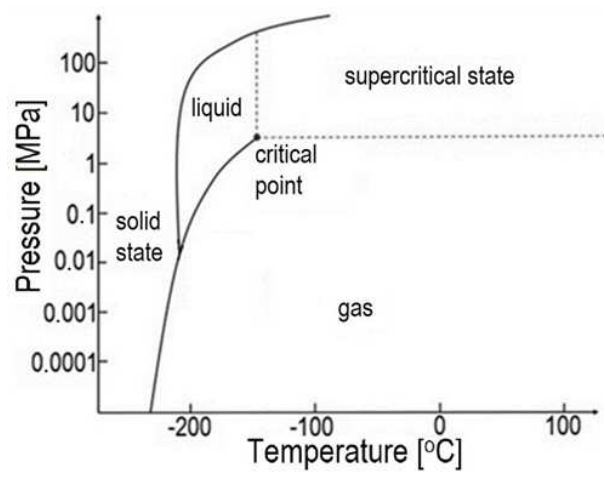

Fig. 2. The temperature-pressure phase diagram for nitrogen

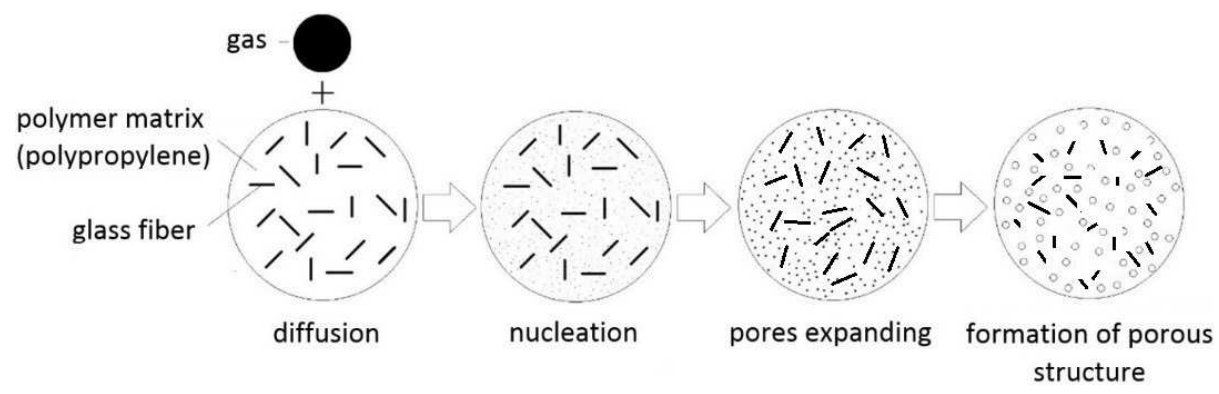

Fig. 3. Diagram of microcellular injection molding process for polymer-fiber composite

In the foaming process these stages take place during the displacement of screw. Higher injection speeds results in a more intense, short-lived reduction of pressure in cavity leading to formation of a dense, porous microstructure. The same fact of pores growth is a complex process dependent on thermodynamic, mechanical and chemical factors [4]. With the increase of the melt temperature, the pore diameter increases. In turn, an increase of polymer volume results in a reverse phenomenon - a decrease of pore diameter, due to the fact that the greater amount of polymer in the cavity reduces the possibilities for enlarging the microcell structure. The increase of mold temperature and injection time results in pore size growing $[7,8]$.

The use of fillers including glass fibers ensures a good quality of porous structure, but it affects larger fiber disorientation occurring around the pores. Thanks to this process it is possible to get a homogeneous porous structure with a variable number of pores: $10^{7}-10^{15}$ pores $/ \mathrm{cm}^{3}$ and a pores size of $0.1-10 \mu \mathrm{m}$ [9-11]. The products formed in this process have lower weight, lack of sinks and deformations, lower processing shrinkage and easier distribution of fibrous fillers $[1,12]$. 


\section{Basics of Mucell ${ }^{\circledR}$ numerical analysis}

For many years, it has been possible to perform a numerical analysis of Mucell ${ }^{\circledR}$ process using specialized commercial codes. During calculations of this process, among others, the phenomenon of solubility, gas diffusion and polymer-gas mixture viscosity are taken into account [13]. The solubility of the gas is usually defined by the equation:

$$
\mathrm{k}=\mathrm{k}_{1} \mathrm{e}^{\frac{\mathrm{k}_{2}}{\mathrm{~T}}}
$$

where: $\mathrm{k}$ - the solubility coefficient,

$\mathrm{T}$ - the temperature,

$\mathrm{k}_{1}, \mathrm{k}_{2}$ - the constant coefficients.

If $\mathrm{k}_{2}=0$, the solubility coefficient $\mathrm{k}$ has a value equal to constant $\mathrm{k}_{1}$.

Gas diffusion equation determines the state in which, after injection to a mold, a gas dissolved in plastic diffuses into the plastic material, followed by nucleation and micropores growth:

$$
\mathrm{D}=\mathrm{d}_{1} \mathrm{e}\left(\frac{\mathrm{d}_{2}}{\mathrm{~T}}\right)
$$

where: $\mathrm{D}$ - the diffusion coefficient,

$\mathrm{T}$ - the temperature,

$d_{1}, d_{2}-$ the constant coefficients.

If $d_{2}=0$, the diffusion coefficient $D$ will have a constant value equal to $d_{1}$.

The viscosity model for polymer-gas mixture made by microcellular foaming technology is usually defined by the equation:

$$
\eta=\eta_{\mathrm{r}}(1-\varphi)^{\mathrm{v}_{1}} \exp \left(\mathrm{v}_{2} \mathrm{c}+\mathrm{v}_{3} \mathrm{c}^{2}\right)
$$

where: $\eta$ - the viscosity of gas-polymer mixture,

$\eta_{\mathrm{r}}$ - the polymer viscosity,

$\varphi$ - volume fraction of gas bubbles,

$\mathrm{c}$ - the gas initial concentration,

$\mathrm{v}_{1}, \mathrm{v}_{2}, \mathrm{v}_{3}-$ the constant factors.

Consideration of complex composite properties in structural calculations is possible by means of homogenization methods. Both analytical and numerical 
methods are used. Most of composites calculations use the Mori-Tanaka model. This method is based on the problem of single inclusions in an infinite, continuous homogeneous medium. In this model, the mean values of stress and strain tensors for inclusions and matrix relate to the tensor of stresses and strains in the macro scale by strain concentration tensor:

$$
\mathrm{B}^{\varepsilon}=\mathrm{H}^{\varepsilon}\left(\mathrm{I}, \mathrm{C}_{0}, \mathrm{C}_{1}\right)
$$

where: $\mathrm{B}^{\varepsilon}$ - the composite strain concentration tensor,

$\mathrm{H}^{\varepsilon}$ - the strain concentration tensor for single inclusion,

I, $\mathrm{C}_{0}, \mathrm{C}_{1}-$ the stiffness matrix of polymer and inclusions.

The mathematical relationship between inclusions and matrix gives an average effect of the interaction between phases [14-16].

\section{Aim of work}

Still expanding range of applications for polymer composites with the porous structure generates the need to carry out numerical simulations [17] of their manufacturing process, as well as the behavior of such products during their use. The results correctness of these analyzes depends largely, among others, on accuracy of defining the properties of these materials. An important issue is the ability to predict the properties of polymer composites with porous considering their heterogeneity. In order to perform this type of analysis both numerical and analytical method of homogenization are often used.

The aim of the study was to evaluate the possibility to manufacture the industrial mop base by means of microcellular injection molding process from polymer-fiber glass composite. The second aim was to evaluate the impact of pores amount on the strength characteristics for three-phase composite. Simulations were subjected to industrial product, taking into account the real conditions of manufacturing and subsequent use of a product.

\section{Numerical simulations}

Simulations of microcellular injection molding process were performed using the industrial mop base model (Fig. 4a) with overall dimensions approx. $600 \times 400 \times 40 \mathrm{~mm}$ (Fig. 4b). The geometric model of a mop base was designed in the NX8 software. Simulations of microcellular foaming process were carried out using Autodesk Moldflow Insight 2013 (AMI 2013). The numerical model, discretised by means of Dual Domain technology consisted of more than 100 thousand of triangular thin shell finite elements. In calculation of microcellular injection molding process the polymer Hostacom G2 N01 (PP $+20 \%$ GF) as polymer matrix was used. 
Several important computer evaluations for composite with fixed and variable processing parameters (Table 1) were performed. Complete cavity filling in each case was observed. Moreover, analyzing the results, a significant difference of fiber orientation can be observed, which is confirmed in the literature $[18,19]$. With an increase of gas content, the average value of fiber orientation tensor decreases, which is particularly evident in the bottom surface of the loaded base (Fig. 5). This phenomenon is probably due to the fibers movement in polymer matrix due to enlargement of the pores which surrounded fibers [19].

a)

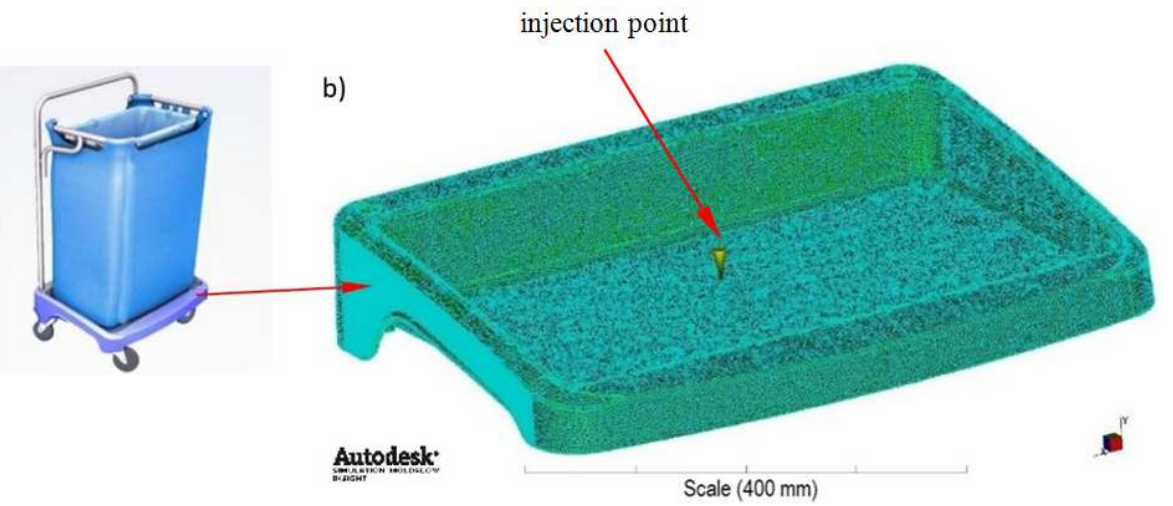

Fig. 4. The industrial mop: a) general view of the device, b) the discretised numerical model of mop base with injection point

Table 1 . The processing parameters used in numerical analyses of microcellular foaming process

\begin{tabular}{|l|c|c|}
\hline \multicolumn{1}{|c|}{ Parameters } & Unit & Value \\
\hline Mold temperature & ${ }^{\circ} \mathrm{C}$ & 80 \\
\hline Melt temperature & ${ }^{\circ} \mathrm{C}$ & 280 \\
\hline Injection time & $\mathrm{s}$ & 3.2 \\
\hline Injection pressure & $\mathrm{MPa}$ & 16.5 \\
\hline Volume filled at start of foaming & $\%$ & $91,95,99$ \\
\hline Number of cells per volume & $1 / \mathrm{cm}^{3}$ & $2 \times 10^{5}$ \\
\hline Initial gas concentration & $\%$ & 0.8 \\
\hline Initial pore diameter & $\mathrm{mm}$ & 0.01 \\
\hline Gas type & - & $\mathrm{CO}_{2}$ \\
\hline
\end{tabular}




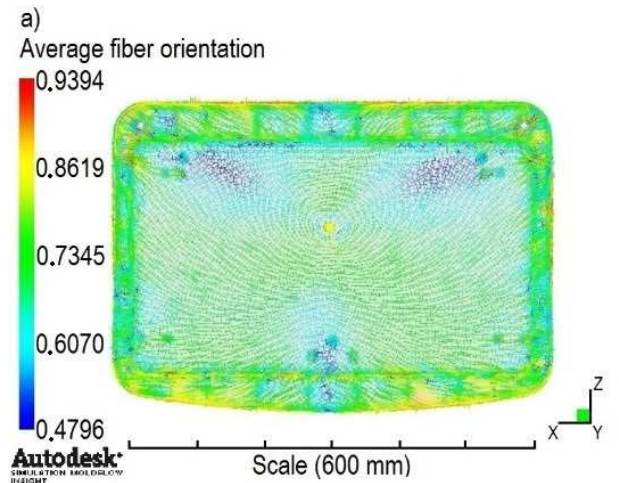

b) Average fiber orientation

Average fiber orientation

Average

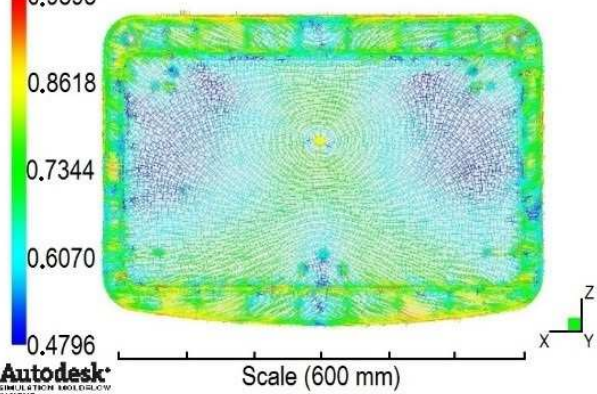

Fig. 5. The fiber orientation after filling of cavity for different gas content: a) for $1 \%$ of gas volume, b) for $9 \%$ of gas volume

\section{Homogenization and analysis of composite structure}

One of the main problems of products strength analysis is the determination of correct material properties. In the case of analyzed composites a three-phase composition should be considered comprising the polymer matrix, fibers and micropores. The structural analysis of this composite was performed using a Digimat MF commercial code, using the Mori-Tanaka homogenization model. This model is often used in properties predicting heterogeneous materials [20]. In order to perform analyzes the material data for every components and the size of geometric inclusions were transferred to Digimat MF. To verify the results, based on literature data [21], the calculation for composite without foaming was performed. Based on good results agreement the next analysis for variable amount of gas, i.e. $1 \%, 5 \%$ and $9 \%$ vol. was performed. The results of the analysis are summarized in the table 2 . Analyzing the results one can notice the fact that with pores increasing the noticeable deterioration in the strength properties occurs. The density reduction of products with increasing of gas contents is also observed. The calculated stress-strain composites characteristics for variable contents of gas in elastic range is shown in figure 6 . The calculations allowed also to obtain the stiffness matrices for four considered material compositions (Fig. 7).

Fibers and pores orientation in the matrix resulting in the calculation is shown symbolically by means of a representative volume element (RVE) for variable degrees of porosity. During calculation, in order to visualize the orientation of inclusions in the polymer matrix, the actual geometric data for fiber polymer matrix and pores were also used. Based on the analysis of the literature $[22,23]$ the fiber length equals $0.25 \mathrm{~mm}$ and fiber diameter equals $0.001 \mathrm{~mm}$ were adopted. 
Table 2. Summary of selected properties of analyzed composites calculated by means of homogenization methods

\begin{tabular}{|c|c|c|c|c|}
\hline Materials and data source & $\begin{array}{c}\text { Young's } \\
\text { modulus } \\
\text { MPa }\end{array}$ & $\begin{array}{c}\text { Poisson's } \\
\text { ratio }\end{array}$ & $\begin{array}{c}\text { Kirchhoff } \\
\text { modulus } \\
\mathrm{MPa}\end{array}$ & $\begin{array}{c}\text { Density } \\
\mathrm{kg} / \mathrm{m}^{3}\end{array}$ \\
\hline Hostacom G2 N01 - literature data [21] & 2900 & - & - & 1040 \\
\hline $\begin{array}{c}\text { Hostacom G2 N01 } \\
\text { (Mori-Tanaka - homogenisation model) }\end{array}$ & 2778 & 0.375 & 1011 & 1065 \\
\hline $\begin{array}{c}\text { Hostacom G2 N01+ 1\% of pores (Mori- } \\
\text { Tanaka - homogenisation model) }\end{array}$ & 2723 & 0.373 & 992 & 1055 \\
\hline $\begin{array}{c}\text { Hostacom G2 N01+ 5\% of pores } \\
\text { (Mori-Tanaka - homogenisation model) }\end{array}$ & 2515 & 0.365 & 922 & 1012 \\
\hline $\begin{array}{c}\text { Hostacom G2 N01+ 9\% of pores } \\
\text { (Mori-Tanaka - homogenisation model) }\end{array}$ & 2322 & 0.357 & 856 & 970 \\
\hline
\end{tabular}

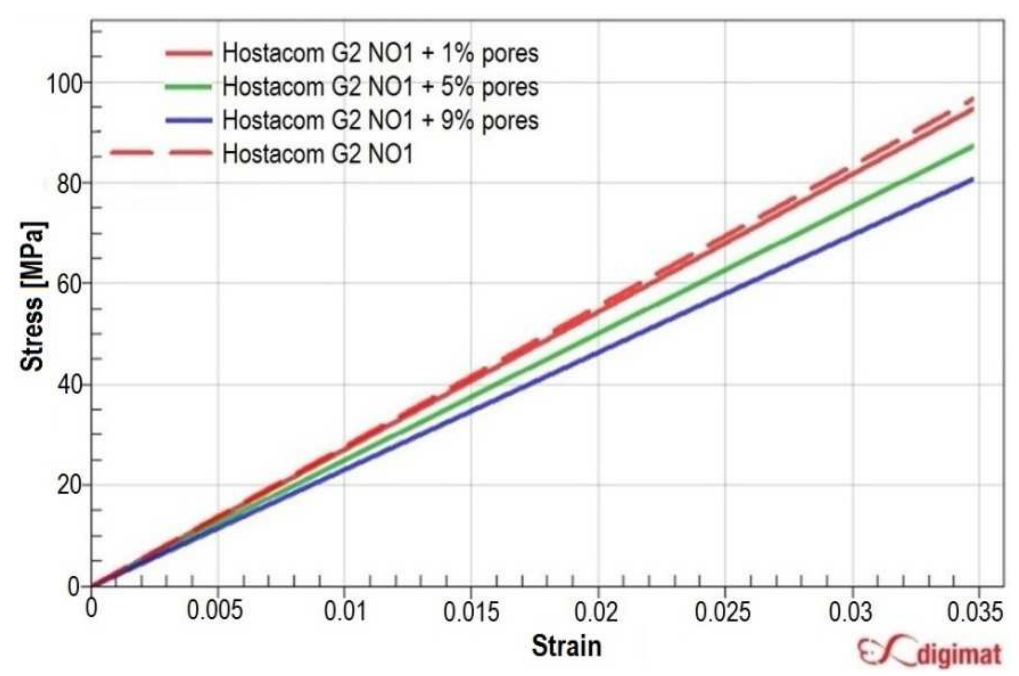

Fig. 6. The stress-strain characteristics for PP-GF composite without and with $(1-9) \%$ of pores

Because of the high value of L/D ratio the sphero-cylinder geometry of fiber shape was defined. The pore geometry as spherical with a diameter of 0.01 $\mathrm{mm}$ was assumed [24]. Due to the complex structure of the composite and the resulting computing problems the specified dimensions of RVE as $0.27 \times 0.27 \times 0.27 \mathrm{~mm}$ were set - big enough that in each direction was at least one fiber - and small enough to perform the visualization. The visualization results for four composite structures are shown in figure 8. 
a)

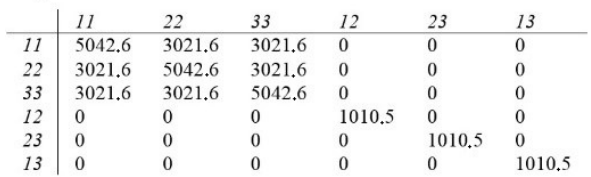

c)

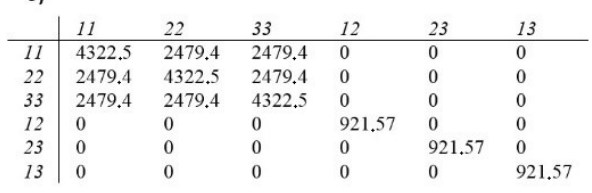

b)

\begin{tabular}{l|llllll} 
& 11 & 22 & 33 & 12 & 23 & 13 \\
\hline 11 & 4891.8 & 2907.9 & 2907.9 & 0 & 0 & 0 \\
22 & 2907.9 & 4891.8 & 2907.9 & 0 & 0 & 0 \\
33 & 2907.9 & 2907.9 & 4891.8 & 0 & 0 & 0 \\
12 & 0 & 0 & 0 & 991.96 & 0 & 0 \\
23 & 0 & 0 & 0 & 0 & 991.96 & 0 \\
13 & 0 & 0 & 0 & 0 & 0 & 991.96
\end{tabular}

d)

\begin{tabular}{l|llllll} 
& 11 & 22 & 33 & 12 & 23 & 13 \\
\hline 11 & 3842.9 & 2131.9 & 2131.9 & 0 & 0 & 0 \\
22 & 2131.9 & 3842.9 & 2131.9 & 0 & 0 & 0 \\
33 & 2131.9 & 2131.9 & 3842.9 & 0 & 0 & 0 \\
12 & 0 & 0 & 0 & 855.51 & 0 & 0 \\
23 & 0 & 0 & 0 & 0 & 855.51 & 0 \\
13 & 0 & 0 & 0 & 0 & 0 & 855.51
\end{tabular}

Fig. 7. The stiffness matrices for: a) Hostacom G2 N01, b) Hostacom G2 N01 with $1 \%$ vol. of pores, c) Hostacom G2 N01 with 5\% vol. of the pores, d) Hostacom G2 N01 with 9\% vol. of pores
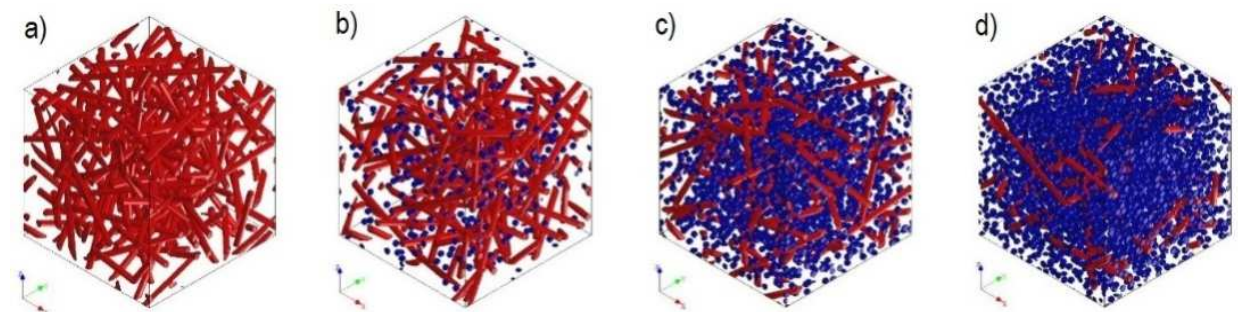

Fig. 8. RVE visualization of PP-GF composite structures: a) without pores, b) for $1 \%$ of pores, c) for $5 \%$ of pores, d) for $9 \%$ of pores

\section{Strength analysis}

Strength analysis was performed in Ansys ver. 14.5 commercial code. Before performing the simulation the boundary conditions were defined. Numerical model of mop base was fixed in wheels mounting places and loaded with extremely adverse force of $200 \mathrm{~N}$ applied to the top surface of the mop base (Fig. 9).

In order to use during structural calculation the material data for composite PP-GF, for the cases without and with $1 \%, 5 \%, 9 \%$ by volume of pores the special Plug-in of Digimat CAE code was implemented inside of Ansys commercial code. As a result of this Plug-in the material the data concerned of MoriTanaka homogenization were transformed. Four essential computer evaluations were carried out for variable gas contents (0-9)\% vol. Analyzing the results, an increase of mop base deformation with increasing of pores amount in the composite structure is observed (Fig. 10). For composite without pores the maximum deflection is approx. $0.27 \mathrm{~mm}$, whereas for the composite with $9 \%$ of pores max. deflection is approx. $3.22 \mathrm{~mm}$ (Fig. 11). 


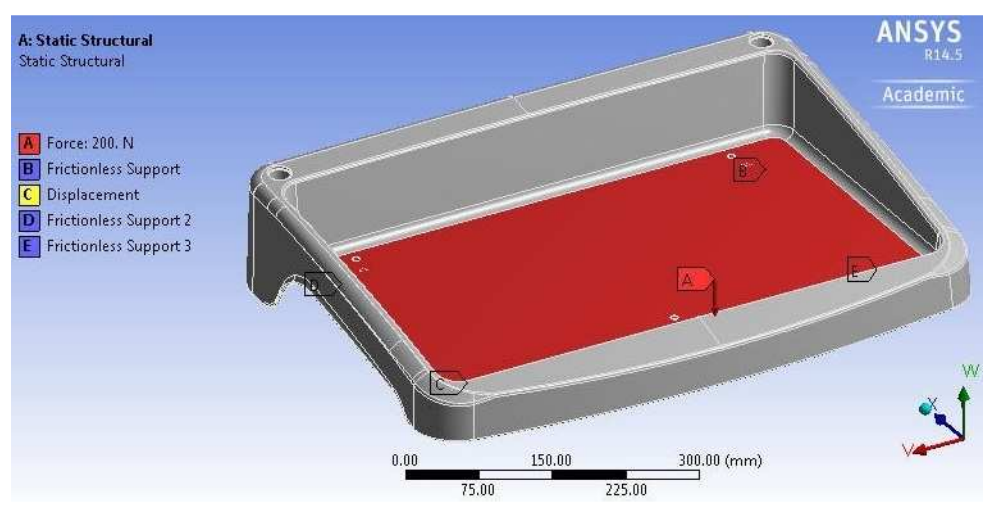

Fig. 9. The loaded surface of mop base with visible supports

\section{Summary}

The numerical analysis of microcellular injection molding process for a usable product made of PP-GF composite was performed. The analysis of results allow to formulate the following conclusions:

- It was found that the increasing number of pores in the composite structure led to increasing the degree of fibers disorientation. This phenomenon results in fibers movement due to the increase of pore volume in their surroundings.

- The strength analysis was carried out taking into account the Mori-Tanaka homogenization model. The high compatibility of strength characteristics for the PP-GF composite in comparison with literature data was found. Based on the satisfactory compliance, strength analysis for variable amount of pores was carried out consecutively. It was found that increasing of pores number in the composite deteriorates its strength properties and reduces density.

oThe microstructure visualization of composites for variable number of pores, taking into account realistic dimensions and shape of the phases, was performed.

oThe numerical analysis of a product load to extremely unfavorable load conditions taking into account the structure of the material was conducted. Based on these results, it was found that with increasing volume fraction of pores, the product may be subject to greater deformation under load of about $17.5 \%$. 


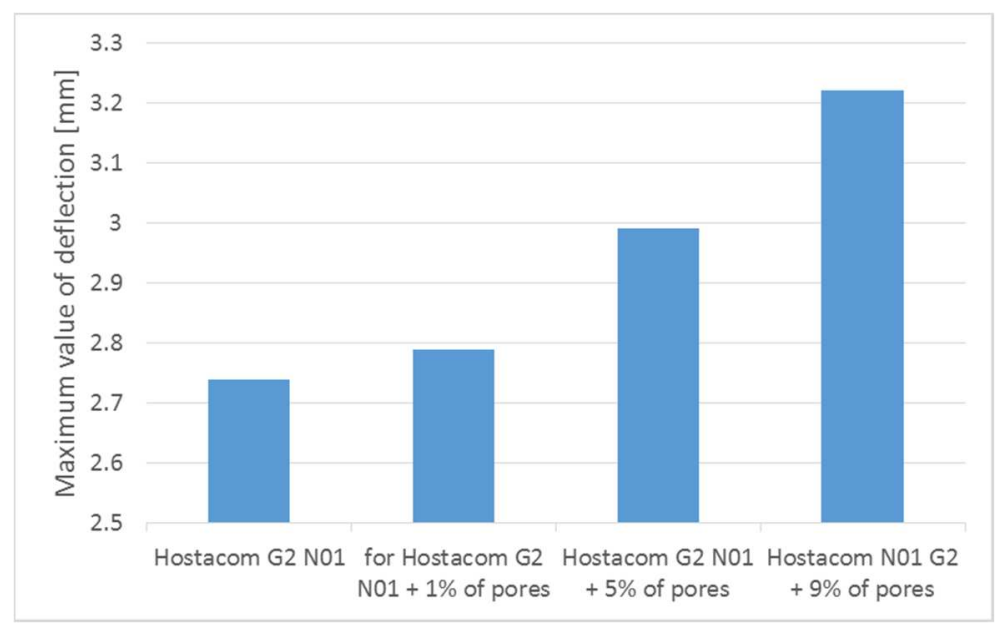

Fig. 10. Maximum deflection value for molded detail with variable content of pores

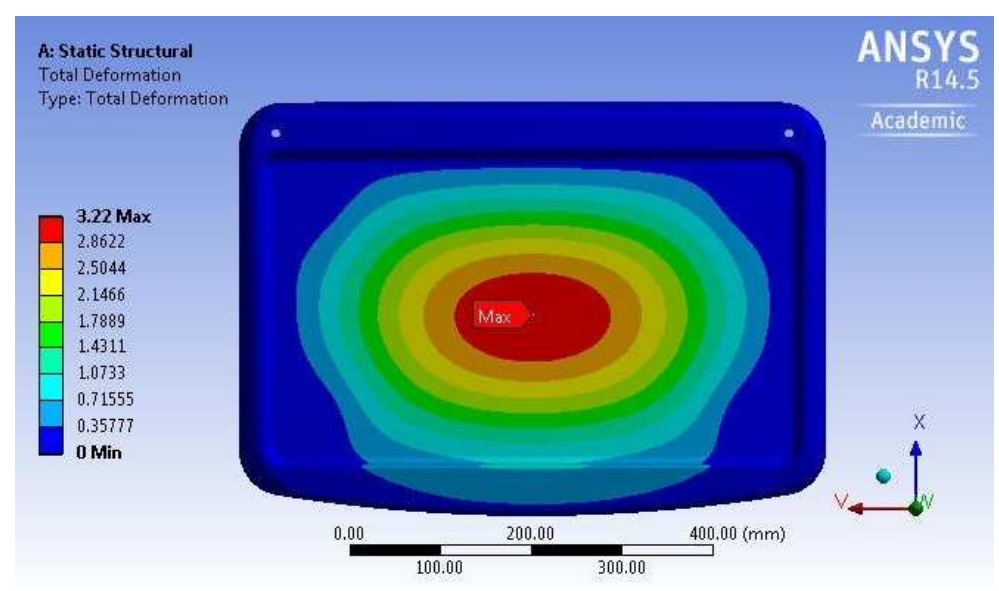

Fig. 11. Deformed areas in the product with maximum deflection value for Hostacom N01 G2 $+9 \%$ of pores

\section{Acknowledgement}

The research leading to these results has received funding from the People Programme (Marie Curie International Research Staff Exchange) of the European Union's Seventh Framework Programme FP7/2007-2013/ under REA grant agreement $\mathrm{n}^{\circ}$ PIRSES-GA-2013-610547.

\section{References}

[1] Bociąga E.: Specjalne metody wtryskiwania tworzyw polimerowych, Wydawnictwo Naukowo-Techniczne, Warszawa 2008. 
[2] Bociąga E.: Wtryskiwanie mikroporujące (MuCell), [in:] (Koszkul J., Bociąga E.(red.), Postęp w przetwórstwie materiałów polimerowych, CWA Regina Poloniae, Częstochowa 2006.

[3] Garbacz T.: Struktura i właściwości porowatych wytworów wtryskiwanych, Polimery, 58 (2013) 295-303.

[4] Bociąga E., Palutkiewicz P.: Wtryskiwanie mikroporujące, Przetwórstwo Tworzyw, 19 (2013) 309-317.

[5] Steinbichler G.: Nowa technologia spieniania drobnokomórkowego wyprasek - MuCell. Technologie wtryskiwania, jakość i efektywność, Wydawnictwo Plastech, Warszawa 2000.

[6] Macyszyn J., Kozłowski M.: Tworzywa termoplastyczne o strukturze komórkowej, http://www.eko-dok.pl/2012/40.pdf (access: 01.01.2017r.)

[7] Bieliński, M.: Techniki porowania tworzyw termoplastycznych, Wydawnictwo Uczelniane Akademii Techniczno-Rolniczej, Bydgoszcz 2004.

[8] Guanghong H., Yu W.: Microcellular Foam Injection Molding Process. Some Critical Issues for Injection Molding, In Tech, Shanghai 2012.

[9] Bravo V.L., Hrymak A.N.: Nozzle injection of physical blowing agents in the injection molding of microcellular foams, Int. Polymer Processing, 20 (2005) 149-156.

[10]Osswald T., Turng L., Gramann P.: Injection molding handbook, Hanser-Gardner, Cincinnati 2001.

[11]Hwang S., Chen S., Chung M.: Study on the mechanical properties of microcellular injection molded parts, ANTEC Conf. Proc., 2 (2005) 776-780.

[12]Palutkiewicz P., Wawrzyniak J.: Wpływ warunków uplastyczniania na właściwości i strukturę wyprasek z PE-HD z poroforem, Przetwórstwo Tworzyw, 18 (2012) 489494.

[13]Palutkiewicz P.: Symulacje komputerowe procesu wtryskiwania porującego, Polimery, 60 (2015) 132-143.

[14]Ogierman W., Kokot G.: Mean field homogenization in multi-scale modelling of composite materials, J. Achievements Mat. Manuf. Eng., 61 (2013) 343-348.

[15]DIGIMAT software documentation, e-Xstream engineering, 2015.

[16]Mori T., Tanaka K.: Average stress in the matrix and average elastic energy of materials with misfitting inclusions, Acta Metallurgica, 21 (1973) 571-574.

[17]Gajdoš I., Duleba B., Spišák E., Greškovič F., Dulebová L.: Optimization of injection molding process by DOE, Hutnik, 81 (2014) 470- 475.

[18]Błędzki A.K., Faruk O., Kirschling H., Kühn J., Jaszkiewicz A.: Microcellular polymers and composites, Polimery, 10 (2006) 697-703.

[19]Ameli A., Jung P.U., Park C.B.: Electrical properties and electromagnetic interference shielding effectiveness of polypropylene/carbon fiber composite foams, Carbon, 60 (2013) 379-391.

[20]Frącz W. Janowski G.: Zaawansowana analiza wytrzymałościowa wypraski z kompozytu WPC z uwzględnieniem powtryskowej orientacji włókien w osnowie polimerowej, Mechanik, 7 (2016) 628-630.

[21]Maier C., Calafut T.: Polypropylene: the definitive user's guide and databook, William Andrew, Norwich 1998. 
[22]Ayadi A., Nouri H., Guessasma S., Roger F.: Determination of orthotropic properties of glass fibre reinforced thermoplastics using X-ray tomography and multiscale finite element computation, Composite Structures, 136 (2016) 635-649.

[23]Mayer P., Kaczmar J.W.: Właściwości i zastosowania włókien węglowych i szklanych, Tworzywa sztuczne i chemia, 6 (2008), 52-56.

[24]Kramschuster A., Cavitt R., Ermer D., Chen Z., Turng L.S.: Quantitative study of shrinkage and warpage behavior for microcellular and conventional injection molding, Polymer Eng. Sci.., 45 (2005) 1408-1418.

\section{WYBRANE ASPEKTY FORMOWANIA ORAZ WYTRZYMAŁOŚCI POLIMEROWYCH KOMPOZYTÓW POROWATYCH W OPARCIU O SYMULACJE NUMERYCZNE}

\section{Streszczenie}

$\mathrm{W}$ pracy przeprowadzono symulacje numeryczne procesu wtryskiwania z mikroporowaniem wypraski z kompozytu polimerowego z włóknem szklanym dla zmiennej zawartości objętościowej porów. W celu oceny wytrzymałościowej trójfazowej struktury kompozytu (matryca polipropylenowa PP, 20\% wag. włókien szklanych WS oraz 1-9\% obj. porów) wykonano analizę mikrostrukturalną oraz przeprowadzono obliczenia wytrzymałościowe z użyciem modelu homogenizacji Mori-Tanaka. Analizowany wytwór (element mopa przemysłowego) poddano symulacji obciążenia w programie Ansys 14.5, określając wpływ zmiennego stopnia porowania na jego właściwości wytrzymałościowe. Ponadto w pracy przedstawiono wizualizację prognozowanej mikrostruktury dla kompozycji przy zmiennym stopniu porowatości kompozytu.

Słowa kluczowe: kompozyty mikroporowate, symulacje numeryczne, Digimat, Ansys, homogenizacja metodą Mori-Tanaka

DOI: $10.7862 / \mathrm{rm} .2017 .03$

Otrzymano/received: 14.02 .2017

Zaakceptowano/accepted: 11.03.2017 
